\title{
MPAcc Postgraduate Education Service For Local Economic Services
}

\author{
Shuoyi He \\ The graduate school, Tianjin University of Finance And Economics, China
}

Keywords: The coordinated development of local economy, MPACC education.

\begin{abstract}
In the circumstances of economic regionalization and international higher education system reform, how to correctly understand MPAcc graduate student education and the relationship between local economic and social development, solve the MPAcc service the actual problems in the local economic development, mining the unlimited potential, which play an important role of it in the local economic and social development, is a very urgent task.
\end{abstract}

\section{Introduction}

The most intense competition in today's regional resources. Shoulder the knowledge innovation and senior professional talents cultivation of higher education in regional economic development plays an increasingly important role, The same MPACC education development scale must be adapted to the local economic development level, The interactive relationship between them. Therefore, MPACC education and local government in strengthening self-development at the same time, must carry out cooperation, to build together, rely on each other to realize the symbiotic development in the process of interaction..

\section{The related theories}

The theory of regional competitiveness. Regional competitiveness mainly refers to the environment in the process of economic globalization the international competitiveness of a country or region economy. In the eight elements of IMD international competitiveness model, science and technology competitiveness, national quality competitiveness is the core competitiveness. 44 national quality competitiveness indicators in 22 of the 26 indicators, science and technology competitiveness with 19 items are related to education, especially related to higher education. So, as an important source of knowledge innovation, technology innovation, innovation ability of colleges and universities, in the regional economic development competition more and more get the attention of people.

Education cost-sharing theory. Education cost sharing theory has two meanings: one is the benefit principle, namely who benefit who should be responsible for the education cost; Two is ability principles, that education investment eventually come from national income, who occupies the national income, for the theory as a whole, who have the ability to bear the education investment. From the point of view of management system, our country and local colleges and universities has central belong to belong. Central belongs to a most colleges to cultivate talents to local jobs, to serve the local economic development. Compared with the central, local countries should be the biggest beneficiaries of higher education. According to the principle of benefit, therefore, local governments should share more cost of education in local colleges, its priority should be to improve the level of the local colleges and benefit and guide the rational allocation of education resources in local colleges, better for the prosperity of local make greater contributions. Regional higher education to improve the overall configuration of resources in colleges and universities in China, give full play to local and various social forces to the school's enthusiasm, promoting the cause of higher education and regional economy better and faster development. 
Unbalanced development theory. Unbalanced development theory is embodied in the higher education, the development of local higher education level and economic development does not adapt, from local economic development level equilibrium configuration, layout of colleges and universities. So, our country's higher education unbalanced development, is our country economic development imbalance in education field. Along with our country economic development level of the formation of gradient structure, eastern, central and western economic development gap is widening, Also means that the total demand for talent, the specifications and structure, is bound to lead to regional higher education hierarchy and professional structure imbalance. The eastern economic developed area, requires a lot of high, refined, sharp technical personnel, high degree of marketization, educational system and the allocation of resources to develop in the direction of marketization; And less developed middle and western areas need more primary and secondary and technical personnel, the marketization degree is low, the education system and the allocation of resources and developed regions is different.

\section{The main foreign universities serving local economic construction}

Production series. After world war ii, countries gradually realize the university in the state or local scientific enterprise, the role of economic growth and social development, one of the most prominent is the emergence of like, American silicon valley "with the core of university of science and technology industrial park" phenomenon, it is the colleges and universities teaching, scientific research, production integration, coordinate, formed a unique production association, become the cradle of high and new technology. At this point, the university to the local economy is no longer a one-way direct relationship with the consultant by the teacher, but with local economic entities, such as the government reached a solidarity partner relationship with brothers.

The local university and symbiotic mode of the regional economy. Interaction between university is university of America in the $1990 \mathrm{~s}$ to produce a new type of model, there are five marks in the process of formation, establish reasonable university's basic structure, combined with the community, the university community at the university of respect, the respect of the community challenge to university and other centered positive attitude. Among them the respect of the so-called community challenge to university, put forward new requirements to community college, university in prosperous community economy, improving people's quality of life of the role of; A positive attitude, for the center with other is university not only willing, and able to absorb the community citizens become school development stakeholder "or" common property ".

Interaction between the growth mechanism of university is closely integrated with the local social and economic development and pursue common interests. Its content includes the following five basic principles: one is the principals to play to the advantages of the school with the potential to solve the problems of the community, so that schools become the force of community development; Second, school and community partnerships, Solve the problem of local concrete; Three is the school attaches great importance to research and solve a major social problem on a nationwide scale, such as economic development, environmental protection, such as unemployment and poverty; Four is the administrative leader of the school and teachers establish "' for the center with other new ideas, overcome only consider the needs of the school and the interests of the old ideas, five is the school developed a careful, clear and community interaction strategy, after a period of practice, has become a new tradition and persistence.

\section{MPAcc education should target localization and characterization in the reform and exploration}

Since March 2004, the national MPAcc teaching refers to the committee in our country at the beginning of establishment, explicitly to explore "application-oriented high-level accounting personnel training mode in China". Initial reference MBA education mode, the main consideration to ensure that the students practice base and the capacity of tuition fees, limited to on-the-job personnel recruit training object. Yet such training more is to meet the specific unit of cultivating senior 
financial management personnel "stock" follow-up education requirements, essentially for MPAcc talents can not supply the society's urgent "incremental demand," thus far away from the "China model" cultivating application-oriented high-level accounting talents has far-reaching great purpose.

Since 2009, to adjust the undergraduate course graduate employment pressure, the structure of the expansion of enrollment MPAcc cancelled "actual work experience" enter oneself for an examination of the constraint conditions, increasing the number of full-time MPAcc education. This change makes a large number of passes through the system training full-time MPAcc graduates will go into the talent market, can be directly adapted to the social and economic development to cultivate high-level accounting personnel "incremental demand," which opens the MPAcc education serve the society.

In 2011, "national special needs talent cultivation project service" to carry out the significance of the first to "service area or industry the urgent demand for talent" set up for the professional master degree education of primary school idea, not only created a professional master's education on the basis of local demand for "ordering guide training special pilot project, more beneficial exploration along with all the" bachelor's degree awarding units to carry out the MPAcc training "model of innovation

In January 2014, the state council degree committee, the ministry of education issued the "on strengthening degree and postgraduate education quality assurance and supervision system of the construction of the opinion" (degree [2014] no. 3) established the basic principles of professional master degree education in the new period of work: "according to the objective demand of social and economic diversification, proper recruitment plan, training mode and degree awarded conditions, and according to the different cultivation subject and object, in terms of quality evaluation and supervision system, implements classified guidance management". On April 10, 2014, director of the MPAcc teaching refers to appoint Yu Weiping in national conference on teaching profoundly pointed out: "MPAcc education must stick to the path of characteristic of running a school, one is to reflect the characteristics of accounting profession, the second is to make the training unit in MPAcc teaching refers to the committee of the nation's overall guidance, combined with its own basis and regional situation, explore the formation has its own characteristics and advantages of MPAcc training mode". Therefore, after ten years' exploration, after the reform of our country MPAcc education are moving into a fully shift to "local demand service, characteristic" of the new period.

But MPAcc curriculum system set up and adjust the pressing needs of the development of local economy lack of good "adaptive" and "agile". On the one hand, the academic degrees committee of the state council issued "the full-time master's degree graduate student guidance training scheme notice (bachelor [2009] no. 23) have the features of guide carefully, principles, a strong, a lot of MPAcc training unit overly constrained in the framework of" training scheme ", on the training direction and the curriculum system setting to well meet the pressing needs of the development of the local and industry.

On the other hand, the local economy and industry demand for talents in the process of transformation in the development of a variety of direct and potential changes, and there is no "agile" reflected in the curriculum setting and teaching of MPAcc run, too much emphasis on the stability of the curriculum system setting, and in the aspect of "large and diverse", agility, much less.

For example, the administrative institutions internal control standard (trial version) "in 2012 (2012) has been in the national administrative business class unit to implement, but each unit MPAcc" government accounting "develop in the direction of the course teaching is mostly didn't pass in the form of" special "and necessary supplement and follow up.

\section{MPAcc graduate education to serve the local economy}

With the continuous development of regional economy in our country, corresponding to the place of higher education, especially the rapid development of higher vocational education. Mouth before local colleges accounted for 93\%. Local institutions of higher learning has become a main part of higher education in our country. Scientific orientation of local colleges and universities, actively serve the local economy, can establish conforms to their own development goals and school-running mode has become the important subject of current higher education development. Influenced by 
traditional education concept of planned economy, China's local colleges did not close with the connection between the local development. Local colleges play a role in regional social and economic development is not enough, the local colleges and universities and the relationship between regional economic benign interaction, coordination development has not yet been established. Relevant government departments lack of institutions of higher learning to a comprehensive understanding of discipline advantage and talent advantages, and institutions of higher learning are not familiar with the requirements of local government departments to organize the school scientific research strength of local construction services, in local government requirements and power of colleges and universities lack basic relationship between the Bridges. Local colleges and universities, we must set up the concept of service for the region's economy, will be located in tenet to serve the local economic construction. This is not only the time development request for local colleges, also accord with the trend of contemporary higher education development. Technological to local, optimize the distribution of local resources, form the local special advantage industries and so on to make due contributions. Should realize that local colleges and regional development is a kind of interactive win-win relationship. Place can have the characteristics of colleges and universities, the key lies in whether act locally to make the right prospective analysis and grasp, the space of development to serve the local economy. Therefore, local colleges and universities and the development of the local government to strengthen self at the same time, must carry out cooperation, to build together, each other.

MPAcc in our country education to "local demand service, characteristic" transformation of the new period, timely introduced "about strengthening degree and postgraduate education quality assurance and supervision system of the construction of the opinions to MPAcc pointed out the curriculum system construction and development requirements:" should be based on objective demand of social and economic diversification, construct the social demand orientation, subject development and student development need scientific and reasonable curriculum system, the combination of all three and update and enrich the content of the course, increase the course type".

First of all, should be clear MPAcc and academic accounting master on the curriculum system of the border. Many colleges and universities are also recruited academic master of accounting and MPAcc students, teachers and the same is also responsible for two classes of graduate student's overall teaching design and teaching tasks. This requires training units in strict accordance with the MPAcc teaching refers to the committee of the nation's guiding ideology, clear MPAcc and academic accounting master fundamental differences in course system and the specific requirements and their boundaries, independently with scientific MPAcc curriculum system overall design and specific configuration. At the same time, according to the cultivating goal setting differs from academic master mentor selection criteria, the curriculum requirements and the way of teaching arrangement and so on, so that the relevant factors of teaching is advantageous to the MPAcc real reasonable and orderly operation of the curriculum system.

Secondly, through the scientific and reasonable design, let the MPAcc curriculum system in the whole education system play a role of "continuity" important cohesion. At present our country has preliminarily established from accounting undergraduate, MPAcc to EMPAcc (advanced) master's degree in accounting, DPAcc (professional doctorate in accounting) applied series degree in accounting education system, as in the middle level of MPAcc education, due to play a role of "continuity" key cohesion. Therefore, on the design of the MPAcc curriculum system, on the one hand, should pay attention to undergraduate professional talent training scheme and accounting of cohesion and cooperation. For example, as a compulsory course for the MPAcc of financial accounting theory and practice, compared to as accounting undergraduate compulsory course of the senior financial accounting, accounting details should skip special accounting items, focusing on the special accounting events accounting methods theory origin and its application in reality economic consequences, and supplemented by the typical case analysis, so as to guide students from the processing of accounting entries into undergraduate level to grasp the economic consequences of accounting method and response to the decision-making level. 
Accelerate the construction of internationalization, expand MPAcc students' international vision. MPAcc international construction is not only an important means of cultivating talents, but also important way of broadening the MPAcc graduate international vision. Push MPAcc action learning and the professional qualification of cohesion, to a certain extent, realize the MPAcc education and industry docking, degree and professional correspondence, the combination of the cultivation and use. "Please come in and go out" strategy to strengthen international cooperation and exchanges in MPAcc. On the one hand, to hire foreign well-known professor of MPAcc graduate students teaching, mainly develops the students' international vision and trains the student to the internationalization of professional ability. Each year, on the other hand, send MPAcc teachers to high-level university study abroad to visit and to attend various academic conferences, industry conference and training program, etc.

In today's society, one that colleges and universities to seek development, must establish the mutual benefit with the local economy and promote each other, the interaction between zero distance contact with society, multi-channel interaction, seek win-win with the local economic development, on the innovative features of colleges and universities has become a lifeline of the development of colleges and universities today.

\section{References}

[1] Wu qiyun. Construction of nantong university and regional economic interaction [J]. Journal of nantong normal university (philosophical social science edition)\} 2004, (12).

[2] Zhang li li, zhang wenmin. Inspiration and inspiration of interactive model of foreign universities and local economic development [J]. Gao jiao exploration, 2005, 6.

[3] Lu jing, local universities and local economic symbiosis development research. The economy of the SAR [J], 2008, 4

[4] Liu yong. The interactive development of local universities and local economy [J]. Journal of new high school, 2006, 10

[5] Molei, qu xiaolong MPACC course system and its operation mechanism optimization problems, [J], commercial accounting, 2015, 6

[6] Meng flame, taking action learning as the main line, training senior accounting practice talents with knowledge and practice, degree and postgraduate student education [J], 2013.12 